JPH RECODE Oktober 2018; 2 (1) : 22-35

http://e-journal.unair.ac.id/JPHRECODE

\title{
DETERMINAN SOSIAL KERENTANAN PEREMPUAN TERHADAP PENULARAN IMS DAN HIV
}

\author{
Desak Made Sintha Kurnia Dewi ${ }^{1}$, Luh Putu Lila Wulandari ${ }^{2}$, D.N. Wirawan ${ }^{3}$ \\ ${ }^{1}$ Departemen Biostatistika dan Kependudukan, Program Studi S1 Kesehatan Masyarakat PSDKU Universitas \\ Airlangga di Banyuwangi \\ ${ }^{2}$ Program Studi Kesehatan Masyarakat, Fakultas Kedokteran, Universitas Udayana \\ ${ }^{3}$ Program Studi Ilmu Kesehatan Masyarakat, Program Pascasarjana, Universitas Udayana Email: \\ desaksintha@fkm.unair.ac.id
}

\begin{abstract}
HIV - AIDS cases are increasing in women and makes them become vulnerable groups. Women have the possibility of infected with STIs - HIV twice higher than men and will have an impact on increasing number of children infections. The study aims to explore social determinants that affect women's vulnerability to STIs - HIV transmission.The study used qualitative design on 21 informants selected purposively that consists of clients, providers, counselors. The selected informant's criterias are currently or had an STI or HIV (client), has experience handling an STI or HIV client (provider / counselor). The recruitment process is carried out by involving health provider. The study was conducted in April - June 2012 at three health services in Denpasar. Data collection was conducted through indepth interviews using semi-structured interview guidelines, then recorded and transcribed. The analysis is done thematically and triangulated through member checking and peer debriefing. The results of the study indicate that the social determinants affecting women's vulnerability to STI-HIV transmission including the lack of knowledge, risky sexual behavior of women and spouses, economic pressures encourage women to engage in prostitution, economic dependence restrict access to services, stigma against condoms and HIV, the influence of gender inequality, women value in community making women in blamed position, low bargaining positions in negotiating sexual relations, motivation, and health provider behavior that affect the quality of service and cause client distrust.Social determinants affect women's vulnerability to STIs - HIV transmission holistically from individual factors of women and beyond individuals, i.e: family, society and culture. A comprehensive efforts froms many parties are needed to improve knowledge, women's empowerment, training about communication and counseling are needed for health provider.
\end{abstract}

Keywords: STIs and HIV, Women's Vulnerability, Bargaining Position, Social Determinants

\begin{abstract}
ABSTRAK
Kasus HIV - AIDS meningkat pada perempuan dan menjadikannya salah satu kelompok rentan. Perempuan memiliki kemungkinan tertular IMS - HIV dua kali lebih besar dibandingkan laki-laki dan berdampak pada meningkatnya jumlah infeksi pada anak. Tujuan penelitian ini untuk menggali determinan sosial yang mempengaruhi kerentanan perempuan tertular IMS - HIV. Penelitian ini menggunakan design studi kualitatif pada 21 informan yang dipilih secara purposive yaitu terdiri dari klien, provider, konselor. Informan yang terpilih adalah pernah atau saat ini mengalami IMS atau HIV (klien), memiliki pengalaman menangani klien IMS atau HIV (provider/konselor). Proses rekrutmen dilakukan dengan melibatkan petugas layanan. Penelitian dilaksanakan pada April - Juni 2012 di tiga tempat layanan di Denpasar. Pengumpulan data dilakukan melalui wawancara mendalam menggunakan pedoman wawancara semi terstruktur, kemudian direkam dan ditranskrip. Analisis dilakukan secara tematik dan triangulasi melalui member checking dan peer debriefing. Hasil penelitian menunjukkan bahwa determinan sosial yang mempengaruhi kerentanan perempuan terhadap penularan IMS -HIV antara lain kurangnya pengetahuan, perilaku seksual berisiko perempuan dan pasangan, tekanan ekonomi mendorong perempuan terlibat dalam pelacuran, ketergantungan ekonomi membatasi akses ke layanan, stigma terhadap kondom dan HIV, pengaruh ketimpangan gender, nilai perempuan di masyarakat menempatkan perempuan sebagai pihak yang dipersalahkan, posisi tawar rendah dalam menegosiasikan hubungan seksual, motivasi, dan perilaku petugas yang kurang mempengaruhi kualitas layanan dan menimbulkan ketidakpercayaan klien. Determinan sosial tersebut mempengaruhi kerentanan perempuan terhadap penularan IMS - HIV secara holistik, dapat dilihat dari faktor individu perempuan dan di luar individu seperti lingkungan keluarga, masyarakat dan budaya. Diperlukan upaya komprehensif berbagai pihak untuk meningkatkan pengetahuan, pemberdayaan perempuan, pelatihan komunikasi dan konseling pasangan bagi petugas kesehatan.
\end{abstract}

Kata Kunci: IMS dan HIV, Kerentanan Perempuan, Posisi Tawar, Determinan Sosial 


\section{PENDAHULUAN}

Kasus HIV meningkat pada populasi perempuan dan menjadi penyebab kematian utama pada perempuan usia 20-40 tahun (The Henry J. Kaiser Family Foundation, 2010). Lebih dari $50 \%$ dari seluruh orang dewasa yang hidup dengan HIV dan AIDS adalah perempuan (Un Women, World Health Organization, 2018) Perempuan memiliki risiko yang rendah terinfeksi HIV karena tidak terbiasa memiliki lebih dari satu pasangan seksual selama hidupnya, tetapi banyak dari mereka masuk dalam kelompok rentan karena perilaku pasangan yang tidak aman diluar pernikahannya serta menggunakan narkoba suntik. Diperkirakan $90 \%$ perempuan yang hidup dengan HIV di Asia tertular akibat hubungan seksual dari suami atau pacar tetapnya (Joint United Nations Programme On Hiv And Aids, 2009, Joint United Nations Programme On Hiv And Aids, 2011).

Indonesia merupakan salah satu negara dengan epidemi HIV yang berkembang paling cepat (National Aids Commission Republic Of Indonesia, 2009a, Avert, 2011a) dengan penularan yang didominasi oleh hubungan heteroseksual.Hasil proyeksi menunjukkan terjadi peningkatan jumlah infeksi baru HIV pada perempuan yang akan berdampak pada meningkatnya jumlah infeksi pada anak (Komisi Penanggulangan Aids Nasional, 2010). Bali menempati peringkat keenam untuk jumlah infeksi HIV di Indonesia pada tahun 2015 (Ditjen P2P Kementerian Kesehatan RI, 2017), termasuk daerah denganpola epidemi HIV terkonsentrasi namun saat ini kasus HIV tidak sepenuhnya terkonsentrasi pada populasi kunci, seperti hasil penelitian yang ditemukan di Bali sebanyak 1,2\% Ibu hamil terinfeksi HIV, yang mengindikasikan kemungkinan ekspansi HIV ke populasi umum (Wirawan, 2011)

Laporan kasus HIV dan AIDS di Kota Denpasar merupakan yang tertinggi di Balidengan kontribusi sebesar40\% dari semua laporan kasus (Dinas Kesehatan Pemerintah Provinsi Bali, 2016). Survey kesehatan reproduksi perempuan oleh Yayasan Rama Sesana (YRS) tahun 2011 di 8 Pasar tradisional di Kota Denpasar menemukan kecenderungan perempuan tidak takut tertular HIV karena beranggapan dirinya setia walaupun mengetahui pasangannya berperilaku berisiko. Temuan lainnya, perempuan yang merasa takut tertular HIV tidak mau menggunakan kondomkarena suami tidak suka atau marah jika menawarkan kondom, Hal ini menjadikan perempuan menjadi salah satu kelompok rentan tertular HIVdimana dua kali lebih besar kemungkinannya tertular melalui hubungan seksual dibandingkan laki-laki (Joint United Nations Programme On Hiv And Aids, 2009).

Trend penderita AIDS pada perempuan terus meningkat dengan rasio laki-laki dibandingkan perempuan pada tahun 2009 adalah 3:1, tahun 2010 adalah 2:1 dan tahun 2011 menjadi 3:2 (Departemen Kesehatan Republik Indonesia, 2009), Kementerian Kesehatan Republik Indonesia, 2011b, Kementerian Kesehatan Republik Indonesia, 2011a). Sejumlah besar infeksi HIV pada perempuan ditularkan oleh suami atau pasangan mereka pada hubungan jangka panjang (Badan Kependudukan Dan Keluarga Berencana Nasional, 2008, Kementrian Pemberdayaan Perempuan Republik Indonesia, 2008, Joint United Nations Programme On Hiv And Aids, 2009, Yayasan, 2009, Avert, 2011b, Mitra, A. \& Sarkar, 2011). Studi dari negara-negara berkembang yang dilakukan oleh Warwick tahun 1998 dan Aggleton tahun 1999 menunjukkan pria dan wanita yang dites dan positif HIV diperlakukan sangat berbeda oleh masyarakat (Mitra, A. \& Sarkar, 2011). dari epidemi HIV menyoroti norma sosial, budaya, dan peran gender yang mengharuskan perempuan tunduk pada dominasi laki-laki dan berkontribusi pada penyebaran HIV(Mitra, A. \& Sarkar, 2011, Madiba dan Ngwenya, 2017, Lekalakala-Mokgele, 2016). Hal ini menjadikan perempuan menjadi kelompok rentan tertular HIV.

Menurut Beijing Platform for Action (BPFA), konsekuensi HIV dan AIDSmempengaruhi kesehatan perempuan dalam peran mereka sebagai ibu dan pengasuh serta kontribusi mereka sebagai penyangga ekonomi keluarga. Perempuan tidak hanya bertanggung jawab dalam melahirkan anak tetapi juga kualitas anak yang dilahirkan, merawat anak, dan melakukan pekerjaan domestik (United Nations Women, 1995). Apabila perempuan terinfeksi HIV, perekonomian keluarga terpuruk, kualitas anak buruk yang berpengaruh pada kualitasnya di masa mendatang.

Kerentanan perempuan terhadap penularan HIV dapat disebabkan oleh beberapa faktor pada level yang berbeda yaitu level individu (biologis, penyakit yang dialami, kesadaran, perilaku seksual), rumah tangga dan masyarakat (status sosial, ketidakstabilan sosial, ekonomi, budaya, stigma dan diskriminasi, rasisme, homophobia, disparitas gender, akses terhadap pendidikan, 
paparan media masa, perilaku dan kekerasan dalam keluarga), dan level makro (lingkungan, migrasi, pelayanan publik, kebijakan, akses ke layanan kesehatan, informasi, dan otonomi) (Avert, 2011b, Illinois Department Of Public Health, no date, United Nations Educational Scientific And Cultural Organization, 2010, Prado, et al., 2013). Melihat kompleksnya permasalahan yang dihadapi perempuan dari berbagai aspek, maka studi ini bertujuan untuk mengetahui determinan sosial kerentanan perempuan terhadap penularan IMS dan HIV.

\section{METODE}

\section{Desain dan Informan Penelitian}

Metode penelitian kualitatif digunakan dalam penelitian ini yang bertujuan menggali secara mendalam determinan sosial yang mempengaruhi perempuan terinfeksi IMS dan atau HIV dan mengeksplorasi kondisi di masyarakat. Pengumpulan data dilaksanakan di tiga tempat layanan di Denpasar yaitu RSUP Sanglah, Puskesmas II Denpasar Selatan dan Yayasan Rama Sesana pada April - Juni 2012. Kota Denpasar dipilih sebagai lokasi penelitian didasarkan pada tingginya kasus HIV yaitu menyumbangkan $40 \%$ dari semua kasus di Bali. Informan sebanyak 21 orang yang terdiri dari 14 klien, 4 orang pemberi layanan (provider) dan 3 orang konselor dipilih secara purposive dengan kriteria pernah mengalami atau saat ini sedang mengalami IMS dan atau HIV (klien), pernah menangani klien IMS dan atau HIV (konselor dan provider), dan mampu diajak berkomunikasi dengan baik, dan bersedia diwawancara. Perekrutan jumlah informan didasarkan atas saturasi data.

\section{Pengumpulan dan Analisis Data}

Penelitian ini telah mendapat Ijin dari Bakesbangpol Provinsi Bali dan dinyatakan laik etik oleh komisi etik Fakultas Kedokteran Universitas Udayana. Metode content analysis digunakan dalam penelitian ini. Cara terbaik untuk merekrut informan penelitian adalah melalui kerjasama antara peneliti dengan petugas dilayanan untuk membantu membangun kepercayaan dan mendorong klien mau berpartisipasi dalam penelitian. Peneliti menjelaskan tujuan, metode dan kriteria informan yang dibutuhkan dari penelitian ini kepada staf dan tenaga kesehatan di lokasi penelitian. Petugas di layanan kemudian akan menjelaskan penelitian ini kepada calon informan untuk mendapat persetujuan awal. Petugas kemudian memperkenalkan klien yang setuju berpartisipasi kepada peneliti baik secara langsung maupun membuatkan janji untuk bertemu. Sebanyak 14 klien, 3 konselor dan 4 provider terpilih dalam penelitian ini. Informan yang terpilih kemudian diberikan penjelasan sebelu persetujuan kemudian menandatangani informed consent sebagai pernyataan kesediaan berpartisipasi.

Pertanyaan yang diajukan saat wawancara antara lain tentang perasaannya terhadap penyakit IMS dan HIV, sumber penularan, bagaimana penyakit tersebut mempengaruhi kehidupannya? bagaimana budaya, kebiasaan mempengaruhi kehidupannya?. Informan diminta untuk berbagi pengalamannya dan memberikan sudut pandang mereka sesuai pengalaman hidup pribadinya. Wawancara dilakukan didalam ruang konseling hanya berdua dengan peneliti. Wawancara berlangsung selama 60 hingga 90 menit. Peneliti mencatat poin poin penting yang muncul saat wawancara dan merekam seluruh percakapan setelah mendapat ijin dari informan. Hasil wawancara kemudian di transkripsi dan dikelompokkan ke dalam tema-tema. Metode triangulasi yaitu peer debriefing dan member checking digunakan untuk mengecek akurasi data.

\section{HASIL}

\section{Karakteristik Informan Penelitian}

Informan berjumlah 21 orang, yang terdiri dari 7 orang perempuan, 7 orang laki-laki, 4 provider (perawat, bidan, dokter) dan 3 konselor HIV. Karakteristik informan ini dilihat dari berbagai aspek diantaranya umur, pendidikan, suku, pekerjaan, lama terinfeksi IMS dan atau HIV dan lama bekerja. Detail informasi dapat dilihat pada tabel 1 . 
Tabel 1. Karakteristik Informan

\begin{tabular}{|c|c|}
\hline Karakteristik & Frekuensi \\
\hline \multicolumn{2}{|l|}{ Vmar } \\
\hline $20-24$ tahum & (6 orang) \\
\hline $25-29$ tahum & (7 orang) \\
\hline 30-34 tahum & ( 3 orang) \\
\hline 35.39 tahum & 4.896 ( 1 orang) \\
\hline 45.49 tahum & $9.5 \%$ (2 orang) \\
\hline$\geq 50$ tahun & ( 2 orang) \\
\hline \multicolumn{2}{|l|}{ Jenis Kelamin } \\
\hline Perempuan & 61.996 (13 orang) \\
\hline Laki-Laki & $38.1 \%$ (8 orang) \\
\hline \multicolumn{2}{|l|}{ Pendidikan } \\
\hline Rendah (Tidak Sekolah - SMP) & $14.3 \%$ ( 3 orang) \\
\hline Tingei (SMA - Perguruan Tingei) & $85.7 \% 6$ (18 orang) \\
\hline \multicolumn{2}{|l|}{ Suku } \\
\hline Bali & $80.9 \% 6(17$ orang $)$ \\
\hline Jawa & $14.3 \%$ ( 3 orang) \\
\hline Flores & $4.8 \%$ ( 1 orang) \\
\hline \multicolumn{2}{|l|}{ Pekerjaan } \\
\hline Mahasiswa & ( 3 orang) \\
\hline IRT & ( 2 orang) \\
\hline Buruh/Freelamce & ( 3 orang) \\
\hline Karyawan Swasta & ( 5 orang) \\
\hline Wiraswasta & (1 orang) \\
\hline Tenaga Kesehatan & (7 orang) \\
\hline \multicolumn{2}{|l|}{ Lama Terinfeksi } \\
\hline $0-3$ bulan & (7 orang) \\
\hline $4-6$ bulan & (2 orang) \\
\hline $6-12$ bulan & (1 orang) \\
\hline$\geq 13$ bulan $(3.7$ tahum $)$ & (4 orang) \\
\hline \multicolumn{2}{|l|}{ Masa Kerja Tenaga Kesehatan } \\
\hline 0. 12 bulan & (2 orang) \\
\hline 213 bulan $(8-15$ tahum $)$ & $(5$ orang) \\
\hline
\end{tabular}

\section{Pengetahuan Informan Tentang IMS dan HIV-} AIDS

Dalam studi ini, informan ditanyakan beberapa pengetahuan tentang IMS, HIV dan Kondom. Pertanyaan seputar IMS yang diajukan adalah tentang definisi, jenis, cara penularan dan cara pencegahan. Hasil wawancara menunjukkan sebanyak 6 informan dari 14 informan menjawab bahwa IMS adalah penyakit yang titularkan melalui hubungan seks. Ketika ditanya mengenai jenisjenis IMS, 11 informan menjawab jenis-jenis IMS adalah sifilis, herpes dan gonore. 3 informan mengetahui bahwa HIV termasuk ke dalam IMS. Mengenai cara penularan, jawaban informan yang paling banyak adalah melalui hubungan seksual, namun ada 1 informan mengatakan tidak pernah mendengar tentang IMS dan 1 informan menjawab penularannya karena tidak menjaga kebersihan alat kelamin, menular melalui toilet umum dan air yang tidak bersih. Untuk pencegahan IMS, 9 informan mengatakan pencegahannya dengan menggunakan kondom, 4 informan mengatakan jangan bergantiganti pasangan seksual, 2 informan menjawab tidak menggunakan jarum suntik yang tidak steril. Namun ada 2 informan yang menjawab pencegahannya dengan minum obat dan vitamin.

Pertanyaan yang diajukan untuk mengetahui pengetahuan informan tentang HIV dan AIDS yaitu definisi, ciri-ciri orang dengan HIV positif, ciri-ciri orang AIDS, cara penularan danpencegahan. Hanya 3 informan saja yang mampu menjelaskan definisi HIV dan AIDS. Seluruh informan mengetahui bahwa penularan HIV dan AIDS melalui hubungan seksual dan jarum suntik tidak steril, hanya 1 informan yang mengetahui bahwa penularan HIV bisa terjadi melalui Ibu ke Anak. Ketika pertanyaan cara pencegahan diajukan, sebagian besar informan mampu menjawab pencegahan menggunakan kondom, namun masih ada informan yang mengemukakan pencegahannya dengan antiseptik setelah berhubungan, jangan menyentuh sesuatu yang digunakan oleh penderita lain dan hati-hati dalam memilih pasangan.

Pertanyaan tentang manfaat kondom dan akibat tidak menggunakan kondom dalam hubungan seksual berisiko, sebanyak 13 informan menjawab dengan baik yaitu dapat tertular IMS, HIV dan bisa mengalami kehamilan tidak diinginkan. Dari hasil wawancara tersebut seluruh informan belum memiliki pengetahuan yang baik karena belum mampu menjawab pertanyaan yang diajukan dengan lengkap, walaupun seluruh informan mengaku pernah mengakses layanan IMS dan atau HIV serta telah memperoleh konseling dan informasi secara lengkap dari konselor.

\section{Perilaku Berisiko Sumber penularan terbanyak dari Laki-Laki}

Studi ini mengeksplorasi perilaku seksual informan yang menyebabkan mereka terinfeksi IMS dan atau HIV. Temuan dalam studi ini 
menunjukkan bahwa semua informan perempuan mencurigai penularan ke diri nya akibat perilaku berisiko pasangan tetapnya, namun ada 1 informan yang juga menyatakan kemungkinan tertular karena perilakunya sendiri. Adapun perilaku yang dimaksud adalahpengguna narkotika suntik, biseksual, menggunakan jasa pekerja seks, memiliki banyak pasangan seksual, dan tidak konsisten menggunakan kondom. Hal ini disampaikan informan seprti pada kutipan berikut “...pacar dulu sudah almarhum, mungkin dia sudah tahu dirinya HIV tapi gak mengatakan kepada saya gitu, mungkin dia malu ..... Saya tahunya dia ngisep ganja saja saya gak tau dia nyuntik juga. Tu dah disana saya kenanya, karena dia...." (IF05, Accounting Spa, ODHA - Pasangan adalah pengguna narkotika suntik).

“...soalnya dulu ya sebelum saya pacaran sama dia (pasangan saat ini) saya juga pernah gonta ganti pasangan kayak gitu kan saya jadi takut juga. Tu dah saya jujur dulu ..., punya pacar 2 sama cowoknya jadi punya pacar 3 dan jarang juga pakai pengaman...." (IF03, Swasta, IMS Memiliki lebih dari satu pasangan seksual dan tanpa kondom).

Pernyataan informan perempuan tersebut juga dipertegas oleh konselor yang telah menangani banyak klien ODHA dimana penularan pada perempuan lebih banyak bersumber dari suaminya seperti pada kutipan berikut

"...mereka rata-rata ibu rumah tangga, mereka dapatnya dari suami. Kenapa saya bilang seperti itu, karena setelah saya konseling pasangannya, pasangannya ini bilang ya saya pernah nyari pekerja seks, walaupun saya gak bilang sama istrinya...Ada juga dari pasien umum nih kalo pasangannya seneng tukar-tukaran pasangan juga ada". (IK02, Konselor, Perawat Klien menggunakan jasa pekerja seks)

\section{Menggunakan jasa pekerja seks dan inkonsistensi dalam penggunaan Kondom \\ 5 dari 7 informan laki-laki dalam} penelitian ini menyatakan pernah menggunakan jasa pekerja seks untuk mencari kesenangan tetapi tidak konsisten menggunakan kondom. Pada informan perempuan juga menyatakantidak konsistenmenggunakan kodom karena beberapa alasan seperti kurangnya pengetahuan tentang kondom dan manfaatnya, mengurangi kenikmatan, kondom tidak tersedia, malu membeli kondom, pasangan tidak mau menggunakan kondom. “...ya ada alasan-alasan kenapa kadangkadang pakai kondom kenapa kadang nggak make. Katanya tuh kan kalau pakai kondom tu nggak terasa apa gitu” (IF03, Swasta, IMS - tidak nyaman menggunakan kondom)

“...kalau yang sekarang ini gak pernah pakai pengaman, ....dia gak mau coba pakai pengaman. Saya pernah, saya bilang kan mending beli pengaman aja dulu, udah kayak gini kan infeksi- infeksi, maksudnya keputihan-keputihan kayak gini, Cuma waktu itu kita sama-sama malu untuk beli pengamannya" (IF04, Mahasiswa, IMS - Malu membeli kondom)

\section{Hubungan seksual dengan pemaksaan}

Seksualitas melibatkan banyak elemen biologis, sosiokultural dan psikososial. Hubungan seksual yang sehat harus dapat dinikmati kedua belah pihak, tanpa adanya rasa keterpaksaan yang dapat menimbulkan akibat buruk seperti tertular IMS dan HIV. Studi ini menemukan beberapa informan perempuan merasakan keterpaksaan dalam hubungan seksual karena merasa dari segi fisik lebih lemah dibanding laki-laki yang menunjukkan bahwa perempuan ditempatkan pada posisi tersubordinasi termasuk dalam aktivitas seksual serta adanya konsep hegemoni yang menggunakan kombinasi antara paksaan dan kerelaan, seperti beberapa kutipan berikut:

"Dengan pacar yang dulu, dia yang ngajak (hubungan sex), .., dia yang ngajak katanya janji- janji mau ngajak nikah..... Jadi saya kepaksa, nggak ada perasaan apa-apa sebenernya waktu diajak hubungan" (IF02, IRT, ODHA)

"IF04 pernah merasa gak nyaman, keberatan, karena capek. kadang pemaksaan juga. Misalnya, aku lagi gak mood gitu, tapi dianya tetep mau nagih gitu. Ada rasa aku mau nolak..., gimanapun usahanya kita melawan, dia masih tetep kuat dibandingkan ma kita" (IF04, Mahasiswa, IMS)

\section{Faktor Ekonomi terhadap Kerentanan} Perempuan Terinfeksi IMS dan HIV

10 dari 14 informan berstatus pekerja di sektor swasta dan memiliki penghasilan tetap. Jumlah informan yang bekerja lebih banyak ditemukan pada laki-laki dimana rentang penghasilan informan perempuan Rp1,300,000 Rp 5,000,000 dan informan laki-laki antara Rp 400,000 - Rp 6,000,000. Menurut determinan penentu kesehatan, faktor ekonomi seperti status kerja, kemiskinan, pengangguran merupakan 
penentu pentingadayang mempengaruhi kesehatan. Informan perempuan dalam penelitian ini masih sangat tergantung pada pasangan dan keluarganya dalam finansial sehingga membatasi aksesnya mencari layanan medis dan harus menunda pemeriksaan walaupuan telah muncul gejala penyakit karena menunggu biaya berobat dari pasangan

“...ya kalau mau periksa ya saya minta persetujuannya dulu (suami), dia yang kasi uang untuk periksa mbak" (IF02,IRT, ODHA)

"Gejalanya udah setahunan lebih tapi gak periksa. Ga tau kemana lagian kan masih kuliah gak punya uang mbak, masa minta ke orang tua nanti dipikirnya gimana......mikirnya, ih periksa ke RS kan mahal deh, ya akhirnya pacar bilang udah gak apa, sini aku yang anterin dan aku yg bayarin" (IF04, Mahasiswa, IMS)

Terpuruknya perekonomian keluarga juga membuat informan laki-laki memaksa pasangannya untuk menjual diri dan melakukan segala cara seperti hubungan seksual dengan sesama lelaki demi mendapatkan materi. Kondisi seperti ini tentunya memperparah kerentanan perempuan terhadap penularan IMS dan HIV

"baru 5 bulan terakhir ini baru kerja begitu, karena perusahaannya anjlok. .... karena bangkrut terus saya bikin dagang,.... terus musibah lagi, rumah terbakar sampai tinggal 1 pakaian di badan, nah begitulah terus terpaksa kerja begitu.......karena keadaan ekonomi jadi terpaksa saya suruh dia (kerja sebagai WPS), dia ya juga iya, dia kan nurut aja”. (IM 05, Buruh Bangunan Migran, ODHA - Memaksa pasangan menjadi pekerja seks)

“.... Dia (laki-laki) kencan dengan lakilaki, Dah tu ternyata dia itu dibiayai....dikasikan uang, dikasikan modal, sampai dia bisa beli mobil...istrinya sakit duluan dia berobat ke puskesmas ternyata setelah di tes istrinya HIV, trus baru dia belakangan di tes ya HIV juga bahkan sampai anaknya" (IK03, perawat, konselor - Klien laki-laki seks dengan laki-laki)

\section{Faktor Sosial terhadap Kerentanan Perempuan Terinfeksi IMS dan HIV}

Faktor sosial dalam penelitian ini melihat adanya peran gender, stigma dan posisi tawar perempuan dalam hubungan seksual.

\section{Stigma terhadap HIV dan kondom}

Informan penelitian ini masih memiliki pandangan yang buruk terhadap HIV dan kondom.
Jika seorang laki-laki memiliki kondom maka diasumsikan sebagai pelanggan pekerja seks dan bila seorang perempuan memiliki kondom ia akan dianggap sebagai pekerja seks, wanita nakal dan porno.

“... kondom? Berarti anak ini udah nakal gitu, berkesannya cewek nakal gitu” (IF03, Swasta, IMS - Stigma Kondom)

"... jadi orang kalo bawa kondom ya nyari PSK atau cewek PSK gitu, semua dah pada ngomongnya begitu, apa itu..iihhhh" (IF01, Tukang Jahit, ODHA - Stigma Kondom)

Pandangan yang buruk juga terjadi pada HIV yang membuat seseorang malu untuk membicarakannya. Keluhan gatal-gatal yang dialami seseorang dipandang sebagai penderita HIV hingga mengalami trauma hanya melihat tulisan HIV yang menyebabkan tidak mau mencari informasi dan tes VCT walaupun merasa berisiko, seperti pada kutipan berikut:

“...aduh, auk ah, kenapa tau? Nyanan ade tulisan (nanti ada tulisan) HIV dan AIDS, saya trauma sekali sama tulisan itu, di televisi, penderita HIV dan AIDS ini muncul itu sudah langsung saya ganti. Sampai sebegitunya, saya merasa jijik dengan yang namanya HIV dan AIDS" (IF06, IRT, ODHA - jijik dengan HIV)

\section{Ketimpangan gender}

Gender juga memegang peranan penting terhadap kerentanan perempuan terinfeksi HIV. Berdasarkan hasil wawancara ditemukan bahwa perempuan masih berada pada posisi subordinasi dalam hubungan suami istri. perempuan menjadi pihak yang lemah dan tertindas. Kekerasan seksual dapat saja terjadi. Laki-laki adalah kepala keluarga dan perempuan hanya menuruti perintah suami atau pasangan, seperti kutipan wawancara berikut: "kalau di Bali ya, kedudukan perempuan masih dinomor 2 kan, jadi laki masih tetep megang peranan dalam hal keputusan, padahal dalam mencari nafkah walaupun sama penghasilannya tetep laki masih dominan dalam pengambilan keputusan, masih tetep seperti itu disini ya, kadang-kadang ngeluh perempuannya katanya suaminya marah-marah... mungkin keterkaitan dengan sakitnya itu, tapi tetep aja dia nomo 1 gitulah istilahnya... padahal istrinya nyari uang untuk pengobatannya. Artinya memang sih laki-laki selalu ingin dihargai dalam kondisi apapun gitu ya" (IK01, Konselor, Perawat)

Perempuan juga selalu menjadi pihak yang disalahkan apabila terjadi infeksi pada 
pasangannya, walaupun laki-laki menyadari infeksi pada perempuan bersumber dari dirinya namun perempuan yang diminta melakukan pemeriksaan dan laki-laki melakukan pengelakan, sehingga perempuan menerima saja perlakukan pasangan, seperti pernyataan informan berikut : "...mana sih ada pria yang mau disalahkan, eh kamu pasti selingkuh sama orang lain ya? Padahal si pria membawa penyakit ditularkan ke perempuannya, tapi perempuannya yang jadi tersangka. Ya kayak saya ini. Karena $y a$, bentuknya burung ini kan kayaknya suci sekali, bersih gitu kayak gak ada infeksinya, jadi yang terdakwa itu pasti vagina orang perempuan" (IF06, IRT, ODHA)

"...kan gini ceritanya ni pas berhubungan kayaknya dia gini ada putih-putih tu keluar...soalnya di itunya aku (penis) ada kayak gitu, Ini penyakitku menular kayaknya ke dia gitu ... tak tuduh aja dia (pacar).. Langsung aja aku balikin kata-kata langsung nuduh dia. Wah kamu penyakit ini, dapat main sama siapa? Tak gituin. Ngomong-ngomong sampai sumpah- sumpahan gak gitu, ya kalau gak percaya ke dokter aja kayak gitu jadinya. Ke dokterlah, dianya yang bersih gitu” (IM04, Mahasiswa, IMS)

Perempuan menerima perlakuan pasangannya ini karena takut akan konsekuensi ditinggalkan, sedangkan ketika laki-laki yang mengalami infeksi perempuan harus bisa menerima kondisi tersebut dan tetap merawat pasangannya tanpa mempedulikan kesehatannya sendiri. Hal ini disampaikan oleh informan konselor yang banyak menangani klien dengan IMS dan atau HIV, seperti kutipan wawancara berikut:

“...dia awalnya bisa nerima, tapi akhirnya nyeletuklah dia owh pantes, memang dulu tiang (saya) tidak dapatkan perawan gini, gini. Nah, mulai muncul emosinya...tapi akhirnya ditinggal istrinya, trus anaknya meninggal dan ibunya dipulangkan ke rumah asalnya ke Tabanan,. Tapi sebaliknya kalau suaminya yang positif, maka istrinya sayang banget sama suaminya, dia bisa nerima suaminya kayak gimana. Begitu kalau perempuannya....". (IK01, Konselor, Perawat)

\section{Posisi tawar perempuan dalam hubungan seksual}

Kemampuan perempuan dalam melakukan negosiasi untuk perilaku seksual yang aman seperti penggunaan kondom dan menolak hubungan seksual adalah komponen vital dalam strategi penanggulangan HIV dan AIDS serta promosi kesehatan reproduksi. Perempuan yang kurang percaya diri untuk menegosiasikan penggunaan kondomdengan pasangan seksual mereka dapat terpapar pada hubungan seksual tanpa perlindungansehingga berisiko tertular IMS termasukHIV dan akibatnya menjadi lebihrentan terhadap kesehatan seksual dan reproduksi yang merugikan (Exavery et al., 2012)

Berdasarkan hasil wawancara, ditemukan fenomena bahwa perempuan masih lemah dan sulit dalam menegosiasikan penggunaan kondom karena anggapan tidak wajar menggunakan kondom dengan pasangan tetap, memuaskan hasrat seksual pasangan walaupun ada kekhawatiran akan tertular infeksi, seperti kutipan wawancara berikut:

"saya yang paling sering nawarin kondom, kadang suami gak mau tapi tetep saya paksa. Tapi kalo dia nolak ya gak enak lah, apa lah dan dianya juga gak bisa makek ribet katanya, ya gimana ya tetep saja hubungan seks" (IF01, Tukang Jahit, ODHA).

Hal tersebut menjadi sebaliknya, jika perempuan telah terinfeksi IMS dan atau HIV. Laki-laki akan menyetujui tawaran perempuan untuk menggunakan kondom dan inisiasi hubungan seksual, seperti beberapa kutipan pernyataan informan berikut:

"ya saya giniin, Pi pakai kondom, saya kan sudah terinfeksi biar nanti gak tertular juga, biar gak ada kejadian yang lain seperti itu. Akhirnya dia mau pakai" (IF01, Tukang jahit,ODHA)

"Kalau saya menawarkan kondom tu begini, dulu pernah saya belum terapi ada yang mau ngajak hubungan badan. "pakai kondom ya, saya bilang begitu. Oh gak enak gini-gini, ya udah kalau nggak!" akhirnya dia juga bersikeras gak mau. Harus pakai kata saya, saya juga bersikeras. Ya kalau gak ya gak usah hubungan. Dan dia gak berani memperlakukan saya melewati batas...."(IF06, IRT, ODHA)

Perempuan juga tidak memiliki kuasa atas dirinya dan terpaksa melayani pasangannya dengan alasan takut pasangan akan mencari seks ke tempat lain, dianggat tidak menyayangi pasangan, dan merasa lemah dan tidak bisa melawan walaupun merasa terpaksa seperti kutipan pernyataan berikut:

"Pernah sih merasa kepaksa gitu ya waktu hubungan seks. Waktu itu kan pulang kerja udah malam capek trus dia minta, cowoknya mabuk kayak gitu. Saya udah coba nolak tapi saya pikir 
lagi kalau nolak dia tu keluar nyari gitu lo, nongkrong dimana, gak pulang. Walaupun jalaninnya terpaksa ya jalanin aja sih. Terus pernah itu kan gini, kalau nggak mau itu artinya kamu gak sayang gitu, walaupun capek gitu, gimana sih kamu jadi cewek nggak pernah mau ngerti gitu katanya"” (IF03, Swasta, IMS)

\section{Faktor Layanan Kesehatan}

Program untuk mencegah terjadinya penularan HIV dilaksanakan secara komprehensif dengan menggunakan 4 prong sehingga peran tenaga kesehatan sangatlah besar dalam mewujudkannya (Kementerian Kesehatan RI, 2015). Dalam penelitian ini, mencoba menggali bagaimana motivasi tenaga kesehatan dalam menangani klien dan mempengaruhi layanan yang mereka berikan kepada klien. Dalam penelitian ini informan konselor dan provider ada yang awalnya tidak memahami dan tidak memiliki motivasi atau ketertarikan dalam menangani isu-isu IMS dan HIV. Hal yang mendasari lebih banyak pada tuntutan tugas dan keharusan baik dari segi profesi maupun atasan, hanya sebagian kecil yang memiliki motivasi dalam menambah kapasitas diri.

Dalam penelitian ini, ditemukan pula kenyataan bahwa masih ada informan perempuan dan laki-laki yang mengeluhkan tentang layanan yang diterima, diantaranya kurangnya akses informasi tentang tempat layanan IMS dan HIV, seperti kutipan wawancara berikut :

“...karena waktu itu di tempat lain saya kurang tau, kebetulan sama dokternya langsung disarankan ke RS Sanglah" (IFO1)

Selain itu, informan juga mengeluhkan layanan yang diterima seperti perilaku petugas yang tidak bersahabat, kurangnya informasi dan kurangnya privasi. Seperti kutipan berikut

“...itu saya ga ngerti apa-apa, saya disuruh RSUnya cek darah, trus dijelasin nanti kalau ada apa-apa hasilnya bagaimana siap ga menerima? Saya ga ngerti apa maksudnya. Trus bilang gini lagi nanti kalau hasilnya positif atau negative ibu siap gak nerima? Saya ga juga ngerti maksudnya apa. Trus saya cek darah, sampai hasilnya keluar saya ga ngerti, beberapa lama baru saya ngerti kena HIV dan AIDS gitu.... Jadi waktu datang ke RSU itu bukan untuk itu"(IF02, IRT, ODHA - Minim informasi)

"...cuman kemarin tuh saya agak risih kenapa pemeriksaan dalam itu, kan harusnya agak privat, rahasia gitu ya tapi kok banyak yang ngelihat bahkan yang gak ikut menangani juga ikut-ikutan ngelihat. Saya gak suka itu. Males jadinya saya kesana" (IF04, Mahasiswa, IMS Kurang privasi)

"...yang di RS itu, judesnya setengah mati, udah tua judes lagi, dia bilang "ini kurang tanda tangan", trus sama saya " "Ibu saya minta cap" saya juga ngomongnya agak sinis "yang manis sedikit kenapa sih ibu?" saya langsung pergi...iya kelakuannya yang harus dibenahi...oknumoknumnya ini yang harus dibenahi sebetulnya" (IFO6, IRT, ODHA - Nakes kurang bersahabat)

\section{PEMBAHASAN}

Determinan sosial kerentanan perempuan terhadap penularan IMS dan HIV jika dikaitkan dengan model Human Ecosystem of Health (The Mandala of Health), kesehatan dipandang sebagai sesuatu yang holistic, mencerminkan pendekatan ekologis dengan menggambarkan bagaimana interaksi antara budaya dan lingkungan mempengaruhi kesehatan. Menjelaskan peran antara gaya hidup dan perilaku pribadi dipengaruhi, dimodifikasi dan dibatasi oleh proses sosialisasi seumur hidup, serta oleh lingkungan psikososial, termasuk keluarga, masyarakat, nilainilai budaya dan standar (Canadian Council On Social Determinants Of Health, 2015). Kondisi kerentanan perempuan terhadap IMS dan HIV ada kaitannya dengan "Personal Behavior" perempuan dan pasangannya yang dapat menentukan kondisi kesehatan kearah positif atau negatif. Perilaku yang dimaksud adalah kurangnya pengetahuan, tidak konsisten menggunakan kondom dan perilaku seksualnya. Kurangnya pengetahuan akan menimbulkan ketidakpedulian terhadap perilaku berisiko yang terjadi pada pasangan dan lingkungan yang menyebabkan ketidakberdayaan perempuan dan rendahnya kewaspadaan maupun aksi dalam mencegah HIV dan AIDS (Megawati, 2011). Menurut penelitian tentang pengetahuan, sikap dan perilaku ibu hamil dan pasangannya tentang HIV/AIDS di Puskesmas Kabupaten Klungkung, di temukan bahwa sebagian besar informan penelitian tidak memahami tentang HIV dan AIDS dengan baik (Megawati, 2011), padahal pengetahuan maupun sikap seseorang tentang cara penularan infeksi HIV/AIDS akan menentukan perilakunya, seperti dalam penelitian crossectional di Kuala Terengganu menemukan bahwa ada hubungan yang sangat kuat antara pengetahuan dengan perilaku seseorang. Seseorang yang tidak memiliki pengetahuan yang adekuat tidak dapat memahami perilaku berisiko yang meningkatkan 
kemungkinan tertular HIV (Aung, et al., 2013).

Dalam kaitannya dengan faktor yang terdapat diluar individu antara lainperilaku seksual pasangan perempuan (laki-laki) berkontribusi terhadap kerentanan perempuan tertular IMS dan HIV. Laki-laki lebih banyak mengalami IMS dan HIV daripada perempuan (Laksana dan Lestari, 2010) karena adanya kegiatan mencari jasa pekerja seks, beberapa alasannya karena insting dasar lakilaki, pekerja seks lebih menarik dan sempurna, mencari keintiman, mencari hubungan sosial diluar hubungan konvensional dengan pasangan, ingin kendali yang lebih besar (dominasi) atas pengalaman seksual, kegagalan dalam kehidupan seksual, menghindari tanggung jawab atau keterikatan emosional dalam hubungan konvensional, kesepian, penasaran (Westerhoff, 2012, Wilcox et al., 2009). Bagi perempuan gejala IMS tidak khusus, namun adanya riwayat memiliki gejala IMS memperkuat pesanbahwa terjadi inkonsistensi penggunaan kondom di semua jenis hubungan seksual (Jain et al., 2011). Berbagai literatur juga menyebutkan bahwa penggunaan kondom secara benar dan konsisten pada hubungan seksual berisiko merupakan salah satu cara untuk mencegah penularan IMS dan HIV secara efektif tanpa menimbulkan risiko bagi kesehatan (Wulansari, 2009, Laksana \& Lestari, 2010). Perempuan juga menjadi lebih rentan karena adanya hirarki yang tidak mengakui hakhak perempuan sehingga menempatkannya menjadi kelompok yang berada pada rasa tidak aman dan dipaksa melakukan aktivitas seksual. Hal ini memperbesar risiko tertular IMS, kehamilan tidak diinginkan dan aborsi yang tidak aman (World Health Organization, 2009) dan menimbulkan konsekuensi yang lebih serius pada perempuan dibanding laki-laki.

Kontribusi lingkungan ekonomi terhadap kerentanan perempuan terjadi karena terpuruknya perekonomian keluarga sehinggamemaksa perempuan terlibat dalam kegiatan pelacuran, serta adanya ketergantungan finansial yang membatasi akses perempuan ke layanan kesehatan. Seseorang bekerja menjadi pekerja seks atau secara terpaksa melakukan hubungan seks karena memiliki perekonomian yang rendah, sementara tuntutan biaya kebutuhan hidup semakin meningkat (Pakpahan, 2011). Perempuan terlibat dalam prostitusi karena berbagai alasan seperti tunawisma, pelecehan seksual,trauma, kekerasan seksual sebelumnya, penyalahgunaan narkoba dan alkohol, tekanan ekonomi dan kemiskinan
(Womens Support Project, 2009). Kondisi perekonomian seseorang atau sebuah keluarga dapat dimasukkan ke dalam lingkungan psiko sosio - ekonomi yang dapat mempengaruhi kesehatan individu dan keluarga (Schatz, P. \& Dzvimbo, 2011). Seseorang yang tidak memiliki penghasilan dan mengalami tekanan ekonomi dapat terlibat dalam perilaku berisiko dan mempengaruhi kemampuannya dalam menjaga kesehatan.

Lingkungan sosial seperti pandangan keluarga tentang IMS, HIV dan kondom memicu munculnya stigma, adanya ketidaksetaraan genderyang terbentuk dalam keluarga dan masyarakat menempatkan perempuan menjadi pihak yang dipersalahkan, tidak mampu mengontrol perilaku seksual pasangan dan perempuan harus menuruti perintah laki-laki. Ketimpangan gender ini juga memicu posisi tawar perempuan menjadi lemah. Mereka tidak mampu menegosiasikan penggunaan kondom dan menolak hubungan seksual kepada pasangannya memperparah kerentanan perempuan terhadap infeksi. Kerentanan perempuan terhadap IMS dan HIV dipengaruhi juga oleh nilai-nilai budaya yang mempengaruhi respons terhadap stigma. Penarikan diri secara sosial merupakan suatu respons budaya yang disetujui terhadap suatu penyakit serius yang dianggap menular, sebagai akibatnya, penarikan diri dan isolasi menjadi sesuatu yang biasa terjadi sehingga ODHA menolak terapi ARV (Butt, L., et, al., 2010).

Jika stigma dapat dihilangkan maka ketidakpatuhan pemakaian kondom dapat dihindarkan (Hastuti, 2012). Demikian sebaliknya jika stigma terhadap kondom begitu besar maka seseorang akan merasa malu untuk mencari tahu informasi tentang kondom dan akan membuat seseorang tidak mau dan tidak patuh menggunakan kondom dalam setiap hubungan seks sehingga meningkatkan kerentanan mereka untuk terinfeksi IMS dan atau HIV. Hasil sanalisis sebuah penelitian yang membandingkan antara pengetahuan dan prevalensi HIVAIDS menunjukkan ada pengetahuan yang komprehensif dan sikap terhadap HIV/AIDS pada kelompok wanita usia subur dengan prevalensi kejadian HIV/AIDS. Wanita usia subur di provinsi dengan prevalensi HIV/AIDS tinggi mempunyai pengetahuan dan pemahaman yang lebih tinggi dan sikap yang lebih baik terhadap HIV/AIDS (Angkasawati, T. J. \& Arifin, 2010). Pemahaman yang salah tentang penularan mengakibatkan 
munculnya stigma di masyarakat, dalam sebuah penelitian di China menunjukkan ada hubungan yang signifikan antara pengetahuan tentang HIV dengan sikap stigma terhadap ODHA, memiliki pengetahuan yang besar tentang penularan HIV secara signifikan terkait dengan $12 \%$ penurunan terhadap stigma (Li et al., 2017).

Proses interaksi berbagai faktor sosial dan politik yang berkembang berkontribusi terhadap situasi dilematis yang dihadapi perempuan. Ketidakadilan terhadap perempuan berasal dari faktor budaya, sistem nilai atau norma yang berlaku di masyarakat, agama atau kekeliruan cara pandang para perencana dan pengambil keputusan terhadap peran dan status perempuan. Dalam hukum dan pemerintahan, kedudukan dan peran perempuan dan laki-laki adalah sama, namun dalam pelaksanaannya berbeda. Anggapan dimasyarakat bahwa perempuan memiliki sifat memelihara dan fungsinya sebagai ibu rumah tangga membuat perempuan banyak terlibat dalam tanggung jawab domestik sedangkan laki-laki pada bidang publik yang menyebabkan pemisahan yang tajam mengenai peran laki-laki dan perempuan sehingga mengarahkan pada dominasi domestik dan seksual yang pada akhirnya menempatkan perempuan dalam keadaan yang kurang menguntungkan. Norma- norma sosial dan gender yang berlaku di komunitas tidak semua melindungi kesehatan dan hak perempuan seperti adanya pembatasan bagi kemerdekaan dan mobilitas perempuan, ketimpangan dalam kesempatan pendidikan dan pekerjaan, tekanan untuk menikah dan melahirkan anak pada usia dini dan hubungan kekuasaan yang tidak setara yang membatasi kendali perempuan atas kehidupan seksual dan reproduksi mereka. Keadaan tersebut menjadikan perempuan rentan terhadap penularan IMS dan atau HIV karena ketidakmampuan perempuan dalam mengontrol perilaku seksual pasangannya (Kementerian Pemberdayaan Perempuan Republik Indonesia, 2008, Mitra \& Sarkar, 2011).

Perempuan dikonstruksi dengan berbagai macam mitos, menganggap bahwa perempuan itu irrasional atau emosional sehingga perempuan tidak bisa tampil memimpin, berakibat munculnya sikap yang menempatkan perempuan pada posisi yang tidak penting. Perempuan sering dituntut untuk menerima keadaan yang menyudutkannya, ditempatkan pada posisi sebagai korban dan dipersalahkan dalam budaya patriarkhi (Kusuma, 2010).

Budaya ini membuat perempuan harus rela diperlakukan tidak adil dan mendapatkan perlakuan yang kurang mengenakkan seperti pelecehan dan kekerasan seksual, perempuan tidak memiliki kekuatan untuk menolak hubungan seksual sehingga menyebabkan perempuan menjadi lebih rentan terhadap infeksi, serta dipersalahkan ketika infeksi terjadi (Bali Sruti). Mengacu pada konsep The Mandala of Health, gender dapat dimasukkan ke dalam faktor masyarakat dan budaya. Ketimpangan gender yang terjadi merupakan sebuah proses interaksi berbagai faktor sosial dan politik, faktor budaya, sistem nilai atau norma, serta agama.

Remaja dan dewasa mempraktekkan seks yang aman lebih rendah pada pasangan resmi dibandingkan dengan pasangan tidak resminya. Perbedaan akses antara perempuan dan laki-laki dalam hal power atau kekuatan dapat mempengaruhi keputusan dalam hubungan seksual, termasuk tipe hubungan seksual, frekuensi dan perilaku aman. Ketimpangan gender di masyarakat, mengarahkan kontrol kepada laki-laki atas segala keputusan (dominasi) termasuk dalam arena seksual. Hal ini yang menyebabkan perempuan tidak memiliki kapasitas untuk menegosiasikan penggunaan kondom maupun menolak hubungan seksual dengan sukses. Penelitian di India, negosiasi kondom dan keputusan seksual sangat kompleks dan terstigma karena dihubungkan dengan gender dan aturanaturan. Ketika perempuan menawarkan kondom, maka hal tersebut akan menimbulkan kecurigaan terhadap dirinya atau anggapan mencurigai pasangan tidak setia. Perempuan setuju bahwa laki-laki atau suami memiliki kekuatan untuk memutuskan kapan dan bagaimana seks dilakukan dan menggunakan kondom. Selain itu ada anggapan bahwa hanya pekerja seks perempuan yang bisa menginisiasi penggunaan kondom (Mitra dan Sarkar, 2011). Upaya untuk membuat perempuan mampu mengatakan tidak pada hubungan seks tidak aman harus menargetkan pria didalamnya (Proulx, 2014). yang menandakan penggunaan kondom tergantung dari kerjasama antara perempuan dengan pasangan seksualnya dan dinamika kekuatan dalam hubungan. Seseorang dapat berubah perilaku seksualnya menjadi aman apabila ada niat menggunakan kondom yang akan mempengarui sikap dan perilakunya, adanya pengalaman dan konsekuensi dari perilaku seksualnya dimasa lalu.

Layanan kesehatan memiliki kontribusi dalam kerentanan perempuan tertular IMS dan 
HIV dikaitkan dengan kemampuan seseorang untuk menjaga kesehatan mereka yang dipengaruhi olehakses informasi tentang IMS, HIV, dan kondom, kualitas layanan yang diberikan, dan perilaku petugas kesehatan. Apabila akses informasi kurang, kualitas dan perilaku petugas kurang memuaskan maka akan menimbulkan krisis kepercayaan pada klien dan meninggalkan bahkan menolak layanan. Kualitas layanan ada kaitannya dengan motivasi tenaga kesehatan.Motivasi adalah suatu keinginan yang terdapat dalam diri seorang individu yang mendorongnya untuk melakukan suatu perbuatan, tindakan, tingkah laku atau perilaku (Notoatmodjo, 2010). Dengan memiliki motivasi yang baik, maka petugas kesehatan akan terdorong untuk bertindak sesuatu dengan lebih baik dan professional dalam upaya penanggulangan dan pencegahan IMS dan HIV. Menurut penelitian yang dilakukan di RSU swasta di Kota Medan tentang persepsi pasien tentang nilai profesionalisme petugas kesehatan terhadap loyalitas pasien berkunjung ke RS ditemukan fakta $80.6 \%$ pasien yang loyal memiliki persepsi yang baik tentang nilai profesionalisme petugas (Saragih, 2016). Motivasi kerja merupakan faktor kunci dari performa atau kinerja individu dan penentu keberhasilan organisasi. Staff yang termotivasi meningkatkan produktivitas kerja seperti berinteraksi dengan pasien sehingga menentukan kepuasan pasien yang pada akhirnya membantu organisasi dalam mencapai tujuan (Rosak-Szyrocka, 2014). Sehingga apabila tenaga kesehatan, provider ataupun konselor memiliki motivasi yang tinggi dalam menanggulangi permasalahan IMS dan HIV maka kualitas layanan yang diberikan kepada klien juga menjadi lebih baik dan menimbulkan kepuasan bagi klien dan loyal untuk datang ke layanan untuk sekedar mengakses informasi dan melakukan upaya pencegaan yang berkontribusi pada penurunan risiko penularan ke orang lain.

Determinan sosial ini dikaitkan dengan model kesehatan mandala dan determinan sosial kesehatan dapat digambarkan seperti pada gambar 1. Sintesis Determinan Sosial dengan Model Kesehatan Mandala dan Determinan Sosial Kesehatan berikut.

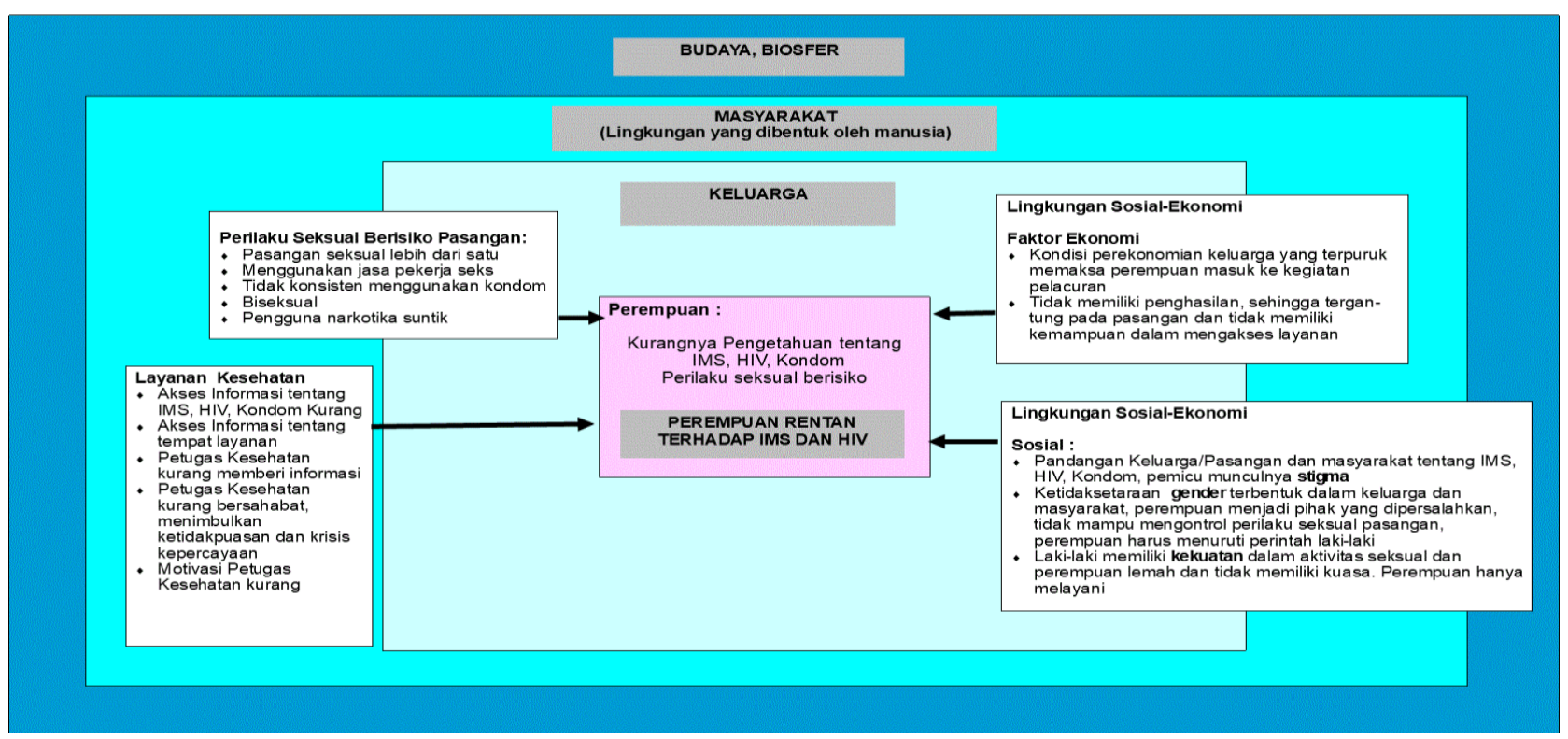

Sumber: data primer

Gambar 1. Sintesis Determinan Sosial dengan Model 


\section{KESIMPULAN DAN SARAN}

Determinan sosial yang mempengaruhi kerentanan perempuan terhadap penularan IMS dan HIV dapat dilihat secara holistik yaitu dari faktor individu perempuan seperti kurangnya pengetahuan individu antara lain lingkungan keluarga, masyarakat dan budaya seperti perilaku seksual berisiko dari pasangan; tekanan ekonomi dan ketergantunganekonomi kepada pasangan membatasi akses perempuan; pandangan pasangan, keluarga dan masyarakat yang memicu adanya stigma; ketimpangan gender yang menempatkan perempuan sebagai korban dan pihak yang dipersalahkan; posisi tawar perempuan yang rendah dalam melakukan negosisasi pada setiap hubungan seksual; serta kurangnya akses informasi, motivasi dan perilaku petugas terhadap klien yang datang ke layanan.

Diperlukan upaya untuk meningkatkan pengetahuan tentang IMS, HIV-AIDS dan kondom pada perempuan untuk meningkatkan kepedulian, mengurangi stigma dan diskriminasi dengan melibatkan tokoh masyarakat; meningkatkan motivasi, kemampuan komunikasi interpersonal tenaga kesehatan dan membuat standarisasi penanganan antara tempat layanan satu dengan lainnya untuk meningkatkan kualitas layanan dan kepuasan klien; meningkatkan pemberdayaan perempuan melalui peningkatan pengetahuan, keahlian dan kemampuan ekonomi untuk memandirikan perempuan dalam membuat keputusan untuk dirinya; Bagi pemangku kebijakan agarmenggalakkan konseling pasangan (couple counseling) terutama pada pasangan tetap; memberikan pelatihan bagi konselor dan provider tentang trik-trik melakukan konseling pasangan

\section{DAFTAR PUSTAKA}

Angkasawati, T. J. \& Arifin, A. 2010. Pengetahuan Komprehensif Dan Sikap Terhadap Hiv/Aids Pada Kelompok Wanita Usia Subur (Wus) Di Indonesia Tahun 2007, Buletin Penelitian Sistem Kesehatan, 13, pp. 140-150.

Aung, Z., Jalaluddin, A. B., Wei, W. K., Htwe, K., Nwe, T., Hassan, M. K. B., Kyaw, Y. M., Aung, S. T., Oo, S. S., Htwe, C. H., Bakar, A. B. A., Tun, K. D. \& Oo, M. 2013. Cross Sectional Study Of Knowledge, Attitude And Practice On Hiv Infection Among Secondary School Students In Kuala Terengganu.
International Journal of Medicine And Medical Sciences, 46.

Avert. 2011a. Hiv And Aids In Asia. Diakses dari: http://www.avert.org/AidsAsia.Htm\#Contenttable3.

Avert. 2011b. Women, Hiv And Aids. Diakses dari: www.Avert.Org.

Badan Kependudukan Dan Keluarga Berencana Nasional. 2008. 1,7 Juta Wanita Terinfeksi Hiv. Diakses dari: Ceria.Bkkbn.Go.Id.

Butt, L., Jack Morin (Djekky R. Djoht), Numbery, G., Peyon, I. \& Goo, A. 2010. Stigma And Hiv/Aids In Highlands Papua Abepura Papua. Research Collaboration Between Pusat Studi Kependudukan Universitas Cendrawasih Dan University Of Victoria.

Canadian Council On Social Determinants Of Health. 2015. A Review Of Frameworks On The Determinants Of Health, Canada, Canadian Council On Social Determinants Of Health.

Departemen Kesehatan Republik Indonesia. 2009. Laporan Triwulan Situasi Perkembangan Hiv\&Aids Di Indonesia Sampai Dengan 31 Desember 2009, Departemen Kesehatan Ri, Jakarta: Kementerian Kesehatan Ri, Direktorat Jenderal Pengendalian Penyakit Dan Penyehatan Lingkungan.

Dinas Kesehatan Pemerintah Provinsi Bali. 2016. Renstra Dinas Kesehatan Provinsi Bali 2013-2018, Bali, D. K. P. (Ed.). Denpasar: Dinas Kesehatan Provinsi Bali.

Ditjen P2p Kementerian Kesehatan RI. 2017. Perkembangan HIV/AIDS dan PMS di Indonesia Januari-Maret 2017, Penyakit, D. J. P. D. P. (Ed.). Jakarta: Direktorat Jenderal Pencegahan Dan Pengendalian Penyakit, Kementerian Kesehatan Ri.

Exavery, A. et al. 2012. Role of condom negotiation on condom use among women of reproductive age in three districts in Tanzania. BMC Public Health. doi: 10.1186/1471-2458-12-1097.

Hastuti, S. 2012. Pengaruh Stigma Hiv/Aids Terhadap Kepatuhan Pemakaian Kondom Pada Pria Odha. Tesis, Universitas Gadjah Mada, Yogyakarta.

Illinois Department Of Public Health. (no date). Fact About Hiv/Aids. Diakses dari: Www.Idph.State.Il.Us/Aids/Default.Htm.

Jain, A. K. et al. 2011. Relationship between reported prior condom use and current selfperceived risk of acquiring HIV among 
mobile female sex workers in southern India. BMC Public Health. doi: 10.1186/1471-2458-11-S6-S5.

Joint United Nations Programme On Hiv And Aids. 2009. Hiv Transmission In Intimate Partner Relationships In Asia. Diakses dari: Unaids.Org.

Joint United Nations Programme On Hiv And Aids. 2011. Hiv In Asia And The Pasific : Getting.

Kementerian Kesehatan Republik Indonesia. 2011a. Laporan Situasi Perkembangan Hiv \& Aids Di Indonesia Sampai Dengan Maret 2011.

Kementerian Kesehatan Republik Indonesia. 2011b. Laporan Situasi Perkembangan Hiv Dan Aids Di Indonesia Sampai Dengan Desember 2010,

Kementerian Kesehatan RI. 2015. Pedoman Manajemen Program Pencegahan Penularan Hiv Dan Sifilis Dari Ibu Ke Anak', Anak, D. J. B. K. I. D. (Ed.).

Kementerian Pemberdayaan Perempuan Republik Indonesia. 2008. Pemberdayaan Perempuan Dalam Pencegahan Penyebaran Hiv-Aids.

Komisi Penanggulangan Aids Nasional. 2010. Strategi Dan Rencana Aksi Nasional Penanggulangan HIV Dan AIDS 20102014.

Kusuma, A. 2010. Perempuan Dan Budaya Patriarkhi Dalam Film "Berbagi Suami”" Karya Sutradara Nia Dinata. Jurnal Ilmu Komunikasi.

Laksana, A. S. D. \& Lestari, D. W. D. 2010. Faktor-Faktor Risiko Penularan Hiv/Aids Pada Laki-Laki Dengan Orientasi Seks Heteroseksual Dan Homoseksual Di Purwokerto, Mandala Of Health, 4.

Lekalakala-Mokgele, E. 2016. Exploring gender perceptions of risk of HIV infection and related behaviour among elderly men and women of ga-rankuwa, Gauteng province, South Africa. Sahara-J: Journal of Social Aspects Of Hiv/Aids, 13. doi: 10.1080/17290376.2016.1218790.

Li, Xin et al. 2017. Factors associated with stigma attitude towards people living with HIV among general individuals in Heilongjiang, Northeast China. BMC Infectious Diseases. doi: 10.1186/s12879017-2216-0.

Madiba, S. and Ngwenya, N. 2017. Cultural practices, gender inequality and inconsistent condom use increase vulnerability to HIV infection: narratives from married and cohabiting women in rural communities in Mpumalanga province, South Africa. Global health action. doi: 10.1080/16549716.2017.1341597.

Megawati. 2011. Pengetahuan, Sikap Dan Perilaku Ibu Hamil Dan Pasangannya Tentang Hiv/Aids Di Puskesmas Klungkung I Dan Puskesmas Dawan Ii Kabupaten Klungkung. Master Tesis, Universitas Udayana, Depansar.

Mitra, A. \& Sarkar, D. 2011. Gender Inequality And The Spread Of Hiv-Aids In India. International Journal Of Social Economics.

National Aids Commission Republic Of Indonesia. 2009. Republic Of Indonesia, Country Report On The Follow Up To The Declaration Of Commitment On Hiv/Aids (Ungass), Reporting Period 2008 - 2009, in Jakarta: National Aids Commission Republic Of Indonesia.

Notoatmodjo, S. 2010. Promosi Kesehatan, Teori \& Aplikasi, ed. revisi 2010. Jakarta: Rineka Cipta. doi: 10.1108/JMTM-03-2018-0075.

Pakpahan, T. 2011. Posisi Tawar Psk Dalam Pemakaian Kondom Sebagai Upaya Mencegah Bahaya Hiv/Aids. Diakses dari: http://repository.usu.ac.id/Bitstream/12345 6789/30475/5/Chapter i.Pdf.

Prado, G., Lightfoot, M. and Hendricks Brown, C.. 2013. Macro-level approaches to hiv prevention among ethnic minority youth: State of the science, opportunities, and challenges. Am Psychol, National Center For Biotechnology Information, 68, pp. 286-299. doi: 10.1037/a0032917.

Proulx, M.-J. 2014. Giving Women The Power To Say "No" Is Essential To Reducing Hiv And Aids: Care. Diakses dari: https://care.ca/Giving-Women-Power-Say"no"-Essential-Reducing-Hiv-And-AidsCare.

Rosak-Szyrocka, J. 2014. Employee's Motivation At Hospital As A Factor Of The Organizational Success, Human Resources Management \& Ergonomics.

Saragih, M. 2016. Persepsi Nilai Profesional Pasien Rawat Inap Dengan Loyalitas Berkunjung Kembali. Idea Nursing Journal, 7.

Schatz, P. \& Dzvimbo, K. P. 2011. The Adolescent 
Sexual World And Aids Prevention: A Democratic Approach To Programme Design In Zimbabwe. Health Promotion International, 16, pp. 127-136.

The Henry J. Kaiser Family Foundation. 2010. Women And Hiv/Aids In The United States. Hiv/Aids Policy. Washington Dc: The Henry J. Kaiser Family Foundation.

Un Women. 2018. Facts And Figures: Hiv And Aids. Diakses dari: http://www.unwomen.org/En/What-WeDo/Hiv-And-Aids/Facts-And-Figures.

United Nations Educational Scientific And Cultural Organization. 2010. Globalization And Women's Vulnerabilities To Hiv And Aids, France, Division For Gender Equality, Unesco'.

Westerhoff, N. 2012. Why Do Men Buy Sex? Diakses dari: https://www.scientificamerican.com/Artic le/Why-Do-Men-Buy-Sex-2012-10-23/.

Wilcox, A. et al. 2009. Tackling the demand for prostitution: a rapid evidence assessment of the published research literature, Home Office.

Wirawan, D. N. 2011. Surveillance On Hiv, in Lessons Learned From Bali. Paper Yang Dipresentasikan Dalam International Seminar On Evidence-Based Programmes For Reproductive Health And Hiv Interventions. Sanur-Bali.

Womens Support Project. 2009. Prostitution. Diakses dari: http://www.womenssupportproject.co.uk/ Content/Prostitution/205,172/.

World Health Organization. 2009. Women's Health. Diakses dari: Www.Who.Int/Entity/Mediacentre/Factsh eets/Fs334/En/.

World Health Organization. 2018. Global Health Observatory (Gho) Data, Number Of Women Living With Hiv. Diakses dari: http://www.who.int/Gho/Hiv/Epidemic_S tatus/Cases_Adults_Women_Children_Te $\mathrm{xt} / \mathrm{En} /$.

Wulansari, S. 2009. Kondom Perempuan, Pemberdayaan Perempuan Dalam Kesehatan Reproduksi, Majalah Kedokteran Indonesia. Jakarta: Ikatan Dokter Indonesia.

Yayasan, S. 2009. Peningkatan Risiko Penularan HIV pada Pasangan Serodiskordan Yang Ingin Memiliki Anak. Diakses dari:
http://spiritia.or.id/News/Bacanews.Php?N wno $=1578$. 